\title{
Konsistensi Penalaran Siswa dalam Pemecahan Masalah Fisika untuk Konteks yang Berbeda
}

\author{
Yuyun Nailufar, Jusman Mansyur dan I Komang Werdhiana \\ yuyunnailufar39@yahoo.com \\ Program Studi Pendidikan Fisika FKIP Universitas Tadulako \\ Jl. Soekarno Hatta Km. 9 Kampus Bumi Tadulako Tondo Palu - Sulawesi Tengah
}

\begin{abstract}
Abstrak -Penelitian ini bertujuan untuk mendeskripsikan konsistensi penalaran siswa dalam pemecahan masalah fisika untuk konteks yang berbeda. Responden yang terlibat dalam penelitian ini sebanyak 6 orang siswa. Data diperoleh melalui Tes Seleksi Responden (TSR), tes esay dan wawancara. TSR terdiri atas 20 butir soal dalam bentuk pilihan ganda. Tes esay terdiri atas 6 butir yang dikerjakan responden dan terakhir adalah kegiatan wawancara. Data penelitian dianalisis melalui pendekatan deskriptif-kualitatif dengan merujuk pada penalaran dalam pemecahan masalah menurut Subaer yang dikaji dari pemecahan masalah menurut Polya. Hasil penelitian menunjukkan bahwa konsistensi penalaran siswa kurang dalam hal ketepatan maupun ketidaktepatan pada konsep fisika yaitu pemuaian, perpindahan kalor secara konduksi, dan perpindahan kalor secara konveksi. Pemecahan masalah untuk tahap mengumpulkan fakta, membangun dan menetapkan asumsi, serta menilai dan menguji asumsi yang dilakukan oleh siswa dalam kategori rendah.
\end{abstract}

Kata Kunci : Konsistensi, penalaran, pemecahan masalah fisika, konteks yang berbeda

\section{PENDAHULUAN}

Seorang siswa dianggap memiliki pemahaman konsep yang konsisten hanya jika dia menjawab dua atau lebih pertanyaan dengan benar yang menguji konsep yang sama, meskipun pertanyaan-pertanyaan ini memiliki konteks yang berbeda sehingga mampu merangsang siswa untuk berpikir dan mendorong siswa menggunakan pikirannya secara sadar dalam memecahkan masalah.

Pemecahan masalah merupakan kemampuan yang perlu dikembangkan dalam pembelajaran. Strategi utama dalam pemecahan masalah adalah penalaran. Penalaran dalam pemecahan masalah merupakan hal yang perlu dikembangkan dalam pembelajaran. Kemampuan pemecahan masalah merupakan hal yang sulit bagi peserta didik dan kemampuan yang dimilikinya masih rendah[1].

Pemecahan masalah yang digunakan mengikuti langkah-langkah pemecahan masalah menurut Polya (1957)[2] yang terdiri dari: memahami masalah, merencanakan penyelesaian, menyelesaikan masalah sesuai rencana, dan melakukan penegecekan kembali. Indikator penalaran yang dikaji berdasarkan langkah-langkah Polya adalah: 1) mengumpulkan fakta, 2) membangun dan menetapkan asumsi, 3) menilai atau menguji asumsi, 4) menetapkan generalisasi,5) membangun argument yang mendukung, 6) memeriksa atau menguji kebenaran argument, 7) menetapkan kesimpulan[3].

Beberapa penelitian yang dilakukan sebelumnya terungkap bahwa kemampuan memecahkan masalah masih sangat rendah.
Apalagi bila siswa tersebut belum menguasai konsep secara matang. Hal ini dapat mengakibatkan ketidakkonsistensian siswa dalam memecahkan masalah walaupun dalam masalah tersebut memiliki konsep yang sama. Berdasarkan suatu studi bahwa siswa sering menggunakan model konseptual mereka secara tidak konsisten ketika memecahkan beberapa pertanyaan yang menguji ide yang sama[4].

Pertanyaan merupakan salah satu instrumen yang digunakan dalam penelitian.Oleh sebab itu, pertanyaan haruslah memiliki struktur agar dapat digunakan untuk mengetahui pola berpikir siswa[5].Penelitian yangmenunjukkan bahwa konsistensi ide atau wacana siswa kelas XI tentang konsep konteks yang berbeda yaitu kecepatan obyek dalam fisika dan laju reaksi kimia. Hasilnya menunjukkan bahwa konsistensi gagasan siswa tentang konsep tingkat di konteks dan domain yang berbeda itu terbatas[6].Selain itu, penelitian oleh Nieminem[7] menemukan bahwa konsisten atau tidaknya seorang siswa dalam memecahkan massalah fisika diketahui melalui jawaban siswa pada soal-soal yang konteksnya berbeda, namun dengan konsep yang sama.

Pernyataan ini mendorong peneliti untuk menyelidiki konsistensi siswa dalam memecahkan masalah fisika untuk konteks yang berbeda pada konsep pemuaian dan perpindahan kalor. Penelitian dilakukan dengan menggunakan konteks yang berbeda yaitu pertanyaan yang berbeda namun memiliki konsep yang sama. 
p-ISSN 2338-3240, e-ISSN 2580-5924

\section{METODE PENELITIAN}

Penelitian ini merupakan penelitian deskriptif-kualitatif yang datanya berupa faktafakta yang ada.Subyek dalam penelitian ini adalah 34 siswa SMA Kelas XI IPA 3 di SMA Negeri 4 Kota Palu Tahun Ajaran 2016/2017. Responden dalam penelitian ini sebanyak 6 (enam) siswa berdasarkan skor Tes Seleksi Responden(TSR) untuk mengerjakan tes esay dan terlibat dalam sesi wawancara.

TSR sebanyak 20 butir soal diberikan kepada 34 siswa. Data dari hasil TSR, dihitung skor rata-rata dan standar deviasi. Skor tersebut dikelompokkan berdasarkan kategori tinggi, sedang dan rendah. Responden yang terpilih diberi tes esaysebanyak 6 butir soal yang memiliki konsep sama namun konteks atau pertanyaan yang berbeda. Hasil lembar jawabannya dibandingkan antara pertanyaan pertama dan kedua yang memiliki konsep yang sama namun konteks yang berbeda untuk melihat konsistensi siswa. Proses pemecahan masalah yang digunakan dianalisis dengan merujuk pada tahap pemecahan masalah menurut Subaer[8] yang dikaji dari Polya[9].

Pemilihan responden untuk pemberian tes TA dan wawancara berdasarkan kategori berikut:

* Kategori tinggi, diperoleh dengan rumus:

$$
\text { Nilai }>\bar{x}+\text { SD }
$$

* Kategori sedang, diperoleh dengan rumus:

$\overline{\mathrm{x}}-\mathrm{SD} \leq$ Nilai $\leq \overline{\mathrm{x}}+\mathrm{SD}$

* Kategori rendah, diperoleh dengan rumus:

$$
\text { Nilai }<\overline{\mathrm{x}}-\mathrm{SD}
$$

Hasil pengelolaan data, skor rata-rata yang diperoleh adalah 47,79 dan nilai standar deviasi adalah 7,09.

Berdasarkan skor rata-rata dan standar deviasi tersebut, Responden yang terpilih untuk terlibat tes esay penalaran dan wawancara berdasarkankategori disajikan pada Tabel 1.

TABEL 1KODE DAN KATEGORI RESPONDEN

\begin{tabular}{ccc}
\hline No & Inisial Responden & Kategori \\
\hline 1 & R-05 & Tinggi \\
2 & R-06 & Tinggi \\
3 & R-14 & Sedang \\
4 & R-33 & Sedang \\
5 & R-21 & Rendah \\
6 & R-28 & Rendah \\
\hline
\end{tabular}

\section{HASIL PENELITIAN DAN PEMBAHASAN.}

Penelitian ini menitikberatkan pada Gbran konsistensi siswa pada konteks yang berbeda dalam pemecahan masalah.Dalam hal konsistensi siswa untuk konteks yang berbeda, peneliti tidak melihat aspek kebenaran atau kesalahan jawaban dari responden pada pengerjaan tes esay.Peneliti hanya mengungkapkan dan mendeskripsikan dari segi konsistensi siswa pada konteks yang berbeda dalam pemecahan masalah.Penentuan peneliti kepada siswa yang konsistenuntuk konteks yang berbeda dalamproblem solving bukan menunjukkan bahwa siswa tersebut dianggap benar dalam problem solving.Sebaliknya siswa tidak konsisten bukan berarti menunjukkan jawaban siswa tersebut salah. Cara siswa menjawabnya berdasarkan pertanyaan dengan konteks yang berbeda namun dengan satu konsep, dari soal tersebut dapat mengGbrkan karakteristik siswa dalam memecahkan masalah fisika yang dapat dikatakan konsistensi untuk konteks yang berbeda. Setelah itu proses pemecahan masalahnya dianalisis berdasarkan tahapan yang dikemukakkan Subaer yang dikaji dari Polya[9].

$>$ Responden dengan TSR Kategori Tinggi

Responden dengan kategori tinggi yakni R05 mampu mengerjakan soal dengan tuntas. Hasilnya menunjukkan bahwa R-05 tidak konsisten pada semua konsep yang diberikan.

Pada soal mengenai pemuaian untuk soal Nomor 1 dan Nomor 2 dengan konteks yang berbeda yang dilakukan oleh R-05 dapat dikatakan tidak konsisten dari segi cara menjawab berdasarkan jawaban R-05. Kutipan jawaban ditunjukan pada potongan lembar jawaban pada Gbr 1 dan Gbr 2.

Proses penalaran dalam pemecahan masalah yang dilakukan oleh R-05 masih kurang untuk tahap mengumpulkan fakta menurut Subaer ${ }^{[3]}$ yang dikaji dari Polya. Hal ini disebabkan R-05 tidak menjawab fakta yang terjadi pada soal yang diberikan, dan ini juga diperkuat dari informasi wawancara R-05 ketika ditanyakan fakta apa yang terjadi R-05 tidak memberikan pernyataan mengenai hal tersebuttetapi R-05 hanya menjawab penyebab gelas retak dan pecah. berikut kutipan jawaban beserta kutipan wawancara dari R-05.

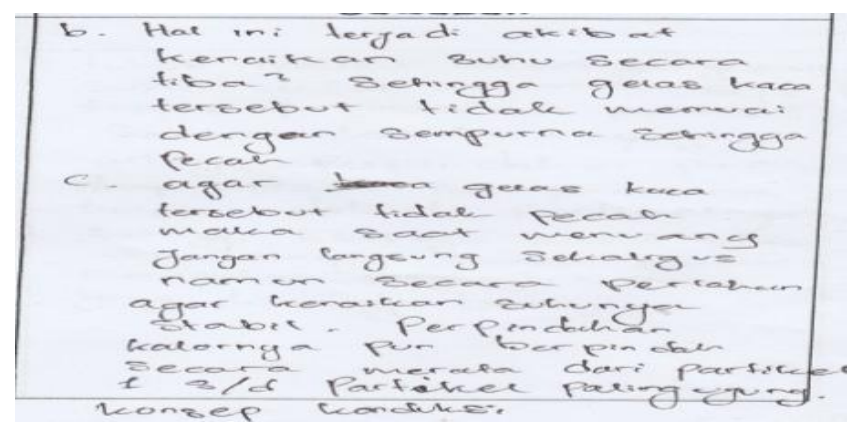

Gbr1 Kutipan Jawaban R-05 No.1 Tentang Konsep Pemuaian 
p-ISSN 2338-3240, e-ISSN 2580-5924

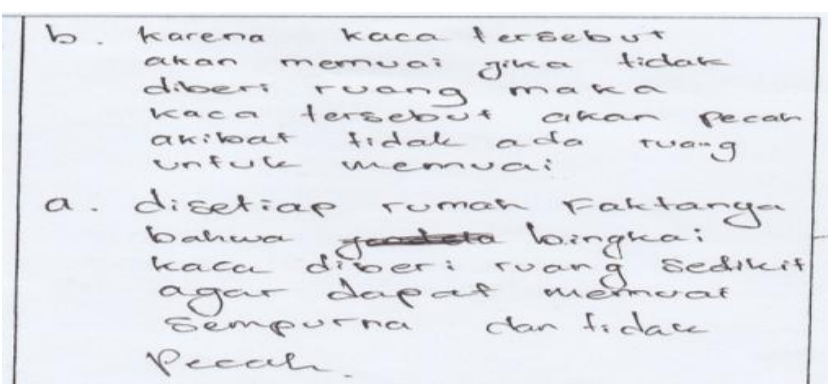

Gbr2 Kutipan Jawaban R-05 No.2 Tentangkonsep Pemuaian

Dalam sesi wawancara penalaran dalam pemecahan masalah yang lakukan oleh R-05 telihat R-05 tidak menjelaskan fakta apa yang terjadi pada soal. Hal ini diperkuat dari hasil wawancara:

\section{$P \quad$ : Paham maksud dari soal No1? \\ R-05: Maksud dari soal No.1 kita diminta untuk menemukan fakta kemudian mengapa hal tersebut bisa terjadi dan penyelesaiannya. \\ $P \quad$ : terus fakta dan mengapa gelas itu retak dan pecah saat dituangkan air panas? \\ R-05: karena bagian dalam gelas kaca itu sudah memuai duluan karena sudah menyesuaikan suhu air panas sedangkan gelas bagian luar belum menyesuaikan suhu air panas sehingga belum memuai sepenuhnya mengakibatkan terjadinya pemuaian dan terjadilah keretakan dan pecah pada gelas tersebut.}

Terlihat dari kutipan jawaban untuk soal Nomor 1 R-05 menjawab bahwa yang terjadi adalah perpindahan kalor secara konduksi, dan pada soal Nomor 2 jawaban telah sesuai dengan konsep yang diminta yaitu konsep pemuaian.

Responden dengan kategori tinggi lainnya adalah R-06. Hasil jawaban menunjukan bahwa R-06 konsisten untuk soal mengenai konsep pemuaian pada soal Nomor 1 dan Nomor 2, dan tidak konsisten pada soal Nomor 3 dan 4 konsep perpindahan kalor secara konduksi dan perpindahan kalor secara konveksi soal Nomor 5 dan Nomor 6.

Proses penalaran dalam pemecahan masalah yang dilakukan R-06 telihat bahwa R-06 sudah dapat mengumpulkan fakta, sedangkan untuk tahap membangun dan menetakan asumsi serta menilai atau menguji asumsi masih rendah.

Salah satu soal yang dikerjakan R-06 dengan konsisten yaitu pada konsep pemuaian untuk soal Nomor 1 dan Nomor 2 untuk konteks yang berbeda.kutipan jawaban ditunjukan pada potongan lembar jawaban pada Gbr3 dan Gbr 4.

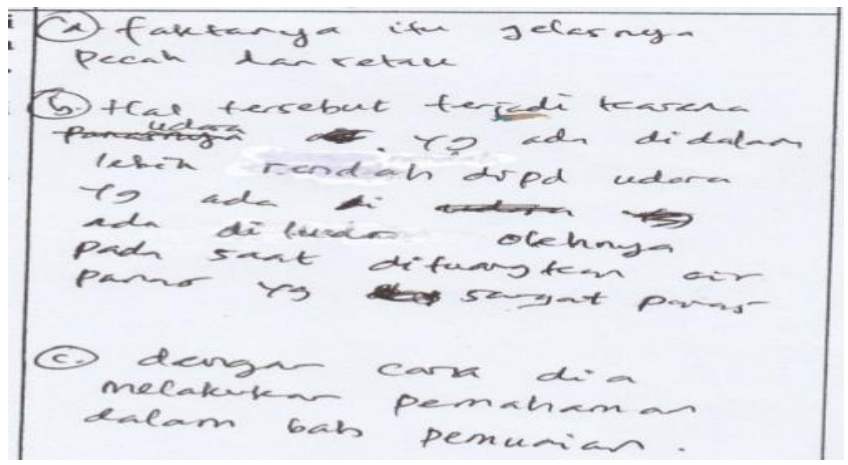

Gbr 3 Kutipan Jawaban R-06 No.1 Tentang Konsep Pemuaian

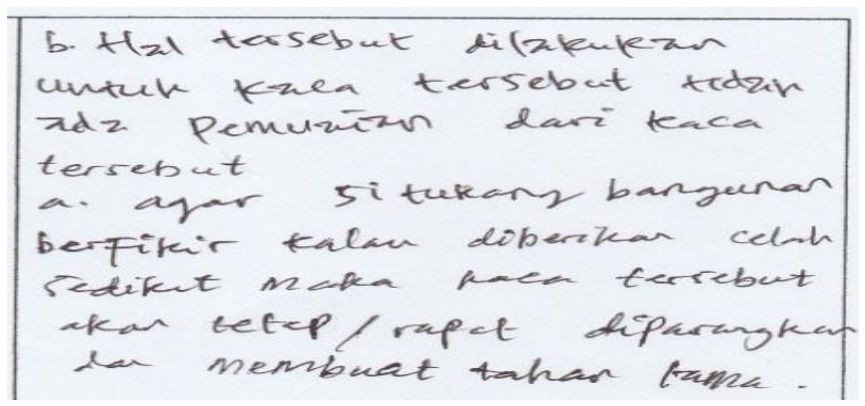

Gbr 4 Kutipan Jawaban R-06 No.2 Tentang Konsep Pemuaian

Pada jawaban Nomor 1 dan Nomor 2 dari R06 mengenai konsep pemuaian untuk konteks yang berbeda, responden dikatakan konsisten. Hal ini dapat dilihat dari kutipan jawaban diatas, untuk soal Nomor 1 R-06 menjawaba sesuai dengan konsep pemuaian, pada soal Nomor 2 punsama R-06 menjawab sesuai dengan konsep pemuaian.

Proses penalaran dalam pemecahan masalah yang dilakukan R-06 untuk konsep pemuaian pada soal Nomor 1, R-06 sudah dapat mengumpulkan fakta yang dikaji dari Polya (1957). Hal ini diperkuat dari hasil wawancara:

\section{P : Anda tahu apa fakta yang terjadi pada soal? \\ R-06 : tahu kak, fakta ketika dituangkan air panas tersebut kedalam gelas tiba- tiba gelas itu retak dan pecah.}

Mengenai soal Nomor 2 masih dengan konsep pemuaian R-06 sudah dapat mengumpulkan fakta yang dimaksud,pada kutipan jawaban R-06 sudah memberikan jawaban yang tepat sesuai dengan tahapan yang diminta, namun tidak dapat menjelaskan secara detail maksud dari konsep yang terjadi pada soal ketika diwawancarai. 
Responden dengan TSR Kategori Sedang

Responden dengan kategori sedang adalah R-14. Hasil jawaban menunjukan bahwa R-14 konsisten untuk soal Nomor 1 dan Nomor 2 dan konsisten untuk soal Nomor 3 dan 4 mengenai konsep perpindahan kalor secara konduksi, dan tidak konsisten untuk soal Nomor 5 dan Nomor 6 mengenai konsep perpindahan kalor secara konveksi.

Untuk soal Nomor 3 dan Nomor 4 mengenai konsep perpindahan kalor secara konduksi, R14 dikatakan konsisten dalam bernalar karena pada jawaban dari kedua soal R-14 menjawab dengan salah atau kurang tepat, sehingga dikatakan konsisten tetapi konsisten salah. Jawaban ditunjukan pada potongan lembar jawaban pada Gbr 5 dan Gbr 6.

$$
\begin{aligned}
& \text { Asamsi mawar ialah } \\
& \text { ia merasa dingin dengan } \\
& \text { tidur-tiduran di lantai. }
\end{aligned}
$$

Gbr5 Kutipan Jawaban R-14 No.3 Tentang Perpindahan Kalor Secara Konduksi

$$
\begin{aligned}
& \text { Asam G- ludah, ta memakai } \\
& \text { selimut agar tubuhnya } \\
& \text { terasa hangat. }
\end{aligned}
$$

Gbr 6 Kutipan Jawaban R-14 No.4 Tentang Perpindahan Kalor Secara Konduksi

Konsistensi pada penelitian ini, peneliti tidak melihat aspek kebenaran, yang dilihat adalah kesesuaian jawaban jika menjawab salah pada kedua Nomor maka dikatakan konsisten tetapi konsisten penaran yang salah.

Proses penalaran dalam pemecahan masalah yang dilakukan untuk tahap membangun dan menetapkan asumsi untuk soal, dapat dikatakan bahwa untuk tahap ini R-14 masih kurang maksimal atau masih rendah. Hal ini diperkuat dengan hasil wawancara, berikut wawancaranya:

\section{$P \quad$ : apa yang tidak dipahami? \\ R-14 : semuanya kak, saya tidak tahu \\ $P \quad$ : sama sekali tidak tahu? \\ R-14 : tidak, paling susah nomor ini kak. \\ $P \quad:$ tentang konsep yang digunakan juga tidak tahu? \\ $R-14$ : Tidak kak}

R-14 tidak menguasai konsep yang terjadi pada soal dan tidak memahami maksud dari soal tersebut. Hal ini juga terjadi pada soal Nomor 4, untuk tahap membangun dan menetapkan asumsi, asumsi yang digunakan masih salah jika disesuaikan pada konsep yang dipakai.

Responden dengan kategori sedang lainnya adalah R-33. Hasilnya menunjukkan R-33 tidak konsisten untuk soal Nomor 1 dan Nomor 2 konsep pemuaian, Nomor 3 dan Nomor 4 konsep perpindahan kalor secara konduksi, dan konsisten untuk soal Nomor 5 dan Nomor 6 konsep perpindahan kalor secara konveksi.

Pada soal Nomor 3 dan Nomor 4 mengenai konsep perpindahan kalor secara konduksi, R33 dikatakan tidak konsisten. Pada soal Nomor 3, R-33 menjawab dengan logikanya tanpa disertai konsep fisika yang memadai, begitupun untuk soal Nomor 4 R-33 tidak paham dengan maksud soal sehingga masih bingung dan tidak menjelaskan konsep fisika yang dimaksud.Seperti yang ditunjukan pada potongan lembar jawaban pada Gbr7 dan Gbr8.

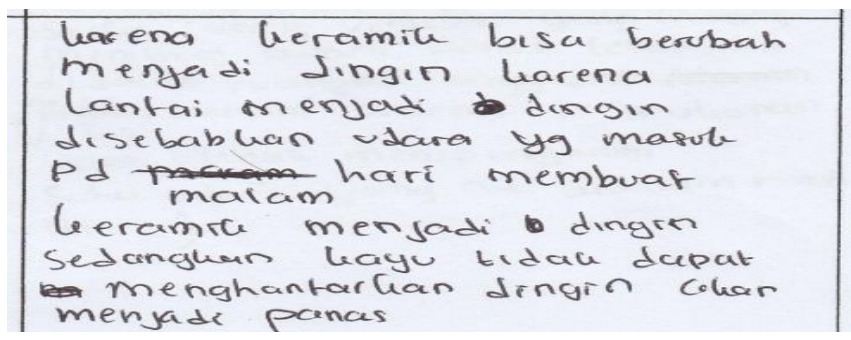

Gbr 7 Kutipan Jawaban R-33 No.3 Tentang Perpindahan Kalor Secara Konduksi

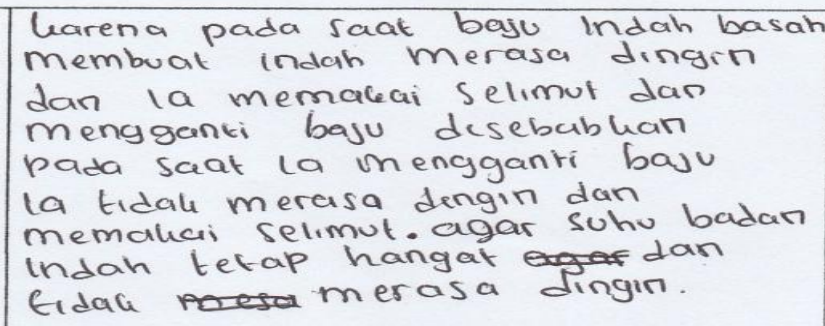

Gbr 8 Kutipan Jawaban R-33 No.4 Tentang Perpindahan Kalor Secara Konduksi

Proses pemecahan dengan menggunakan tahapan penalaran untuk tahap membangun dan menetapkan asumsi masih kurang dan R-33 masih bingung dan tidak paham maksud dari soal.hal ini juga diperkuat dengan hasil wawancara, berikut petikan wawancaranya.

\section{$P \quad:$ untuk Nomor 4, Anda paham?}

R-33 : paham, karena pada saat baju indah basah membuat indah merasa dingin sehingga ia memakai selimut dan mengganti baju agar suhu badan indah menjadi hangat.

$P \quad$ : jadi selimut penghantar kalor yang baik atau buruk?

R-33 : Baik

$P \quad:$ tidak terbalik?

R-33 : Tidak 
p-ISSN 2338-3240, e-ISSN 2580-5924

kalau penghantar kalor yang baik disebut apa?

\section{$R-33$ : isolator mungkin}

R-33 mengakui bahwa dari enam soal yang dikerjakan soal mengenai perpindahan kalor secara konduksi yang jarang ditemui karena responden bingung membedakan antara isolator dan konduktor.

Pemahaman tentang materi suhu dan kalor khususnya pada konsep perpindahan kalor yang dimiliki R-14 dan R-33 sangat kurang menyebabkan pemecahan masalah dalam penalaran yang dilakukan masih rendah.

\section{> Responden dengan TSR Kategori Rendah}

Responden dengan kategori rendah adalah R-21 mampu menyelesaikan soal.Namun, dilihat dari jawaban R-21 konsisten pada soal Nomor 1 dan Nomor 2 mengenai konsep pemuaian, dan tidak konsisten pada Nomor 3 dan 4 tentang konsep perpindahan kalor secara konduksi, serta Nomor 5 dan Nomor 6 mengenai konsep perpindahan kalor secara konveksi.

Salah satu soal mengenai perpindahan kalor secara konveksi dijawab R-21 dengan tidak konsisten. Hal ini ditunjukkan pada lembar jawaban R-03. Seperti pada potongan lembar jawaban pada Gbr9 dan Gbr10.

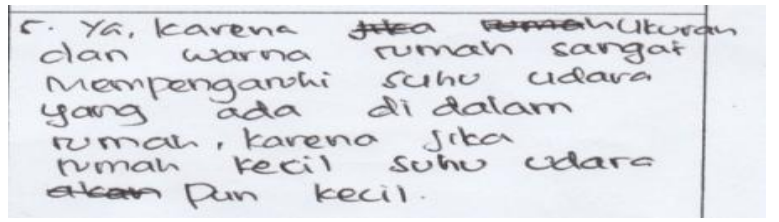

Gbr 9 Kutipan Jawaban R-21 No.5 Tentang Konsep Perpindahan Kalor Secara Konveksi

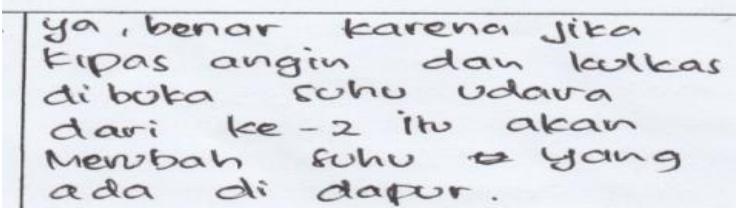

Gbr 10 Kutipan Jawaban R-21 No.6 Tentang Konsep Perpindahan Kalor Secara Konveksi

Berdasarkan lembar jawaban diketahui bahwa R-21 dikatakan tidak konsisten karena hanya salah satu saja yang hampir tepat yaitu untuk soal Nomor 6, untuk soal Nomor 5 jawaban R-21 masih keliru.

Proses penalaran dalam pemecahan masalah fisika untuk soal Nomor 5 dan Nomor 6 untuk tahap menilai dan menguji asumsi terlihat bahwa sumsi yang digunakan masih kurang maksimal. Hal ini juga diperkuat dengan hasil wawancara R-21. Bahwa R-21 belum pernah menjumpai soal yang berbentuk seperti ini. Berikut petikan wawancara.

\section{$P \quad:$ pernah dapat soal seperti ini? \\ $R-21$ : Belum \\ $P \quad$ Menurut Anda susah mana konsep atau perhitungan? \\ $R-21$ : Perhitungan}

Selain R-21, kategori rendah lainnya adalah R-28, terlihat dari jawaban R-28, hasilnya menunjukkkan R-28 tidak konsisten pada soal Nomor 1 dan Nomor 2,konsisten untuk Nomor 3 dan Nomor 4, tidak konsistenuntuk Nomor 5 dan Nomor 6 dengan konsep perpindahan kalor secara konveksi.Seperti pada potongan lembar jawaban pada Gbr11 dan Gbr12.

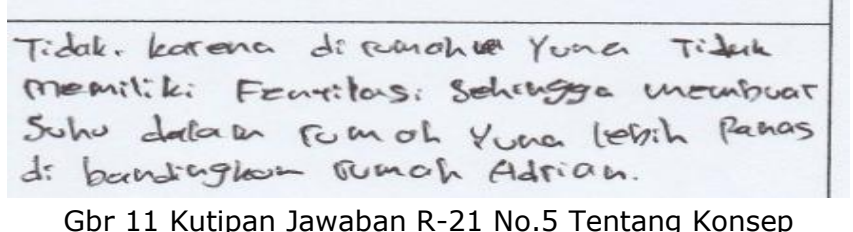

Gbr 11 Kutipan Jawaban R-21 No.5 Tentang Konsep Perpindahan Kalor Secara Konveksi

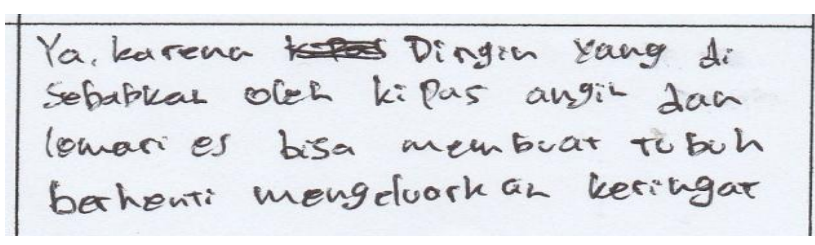

Gbr 12 Kutipan Jawaban R-21 No.6 Tentang Konsep Perpindahan Kalor Secara Konveksi

Untuk soal Nomor 5 dan Nomor 6, R-28 dikatakan tidak konsisten penalarannya karena pada soal Nomor 5 R-28 masih keliru dalam menjawab soal dan untuk soal Nomor 6 R-28 hampir tepat namun hanya menjawab berdasarkan logika tanpa disertai dengan konsep fisika yang dimaksud pada soal. Hal ini diperkuat dari hassil wawancara. Berikut petikan wawancara.

\section{$P \quad:$ paham maksud dari soal ini? \\ $R-28$ : Tidak \\ $P \quad:$ mengapa tidak paham? Apa yang tidak dipahami? \\ $R-28:$ (..) \\ $P \quad:$ pernah dapat soal seperti ini? \\ R-28: Pernah mungkin}

Proses penalaran dalam pemecahan masalah untuk soal Nomor 5 dan Nomor 6 dapat dikatakan masih lemah dalam tahap menilai atau menguji asumsi karena pada jawaban R28 tidak menjelaskan secara detail asumsi yang terjadi benar apa tidak.

Penelitian yang dilakukan pada enam responden dari tiga kelompok kategori yakni kategori tinggi R-05 dan R-06, kategori sedang $\mathrm{R}-14$ daan $\mathrm{R}-33$ dan kategori rendah $\mathrm{R}-21$ dan R-28. Hasilnya menunjukkan konsistensi 
penalaran responden untuk konteks yang berbeda beragam. Pada proses penalaran dalam pemecahan masalah tahap-tahapan dalam menyelesaian masalah fisika berbeda dari masing-masing siswa.

Hubungan konsistensi responden dalam menjawab pertanyaan berdasarkan pertanyaan tidak mempengaruhi proses penalaran pemecahan masalah yang dilakukan oleh responden. Pengaruh konsistensi atau ketidakkonsistensian untuk konteks yang berbeda tidak mempengaruhi proses penalaran dalam pemecahan masalah yang siswa lakukan.
Semua konsistensi keenam responden berdasarkan konteks yang berbeda yang dijawab dari enam butir tes esay disajikan pada Tabel 2 .

TABEL 2 KONSISTENSI PENALARAN UNTUK KONTEKS YANG BERBEDA

\begin{tabular}{|c|c|c|c|c|c|c|c|}
\hline \multirow{2}{*}{ 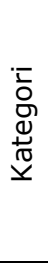 } & \multirow{2}{*}{ 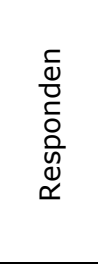 } & \multicolumn{2}{|c|}{ Pemuaian } & \multicolumn{2}{|c|}{$\begin{array}{l}\text { Perpindahan Kalor secara } \\
\text { Konduksi }\end{array}$} & \multicolumn{2}{|c|}{ Perpindahan Kalor secara Konveksi } \\
\hline & & 1 & 2 & 3 & 4 & 5 & 6 \\
\hline ত̄ & R-05 & $\begin{array}{l}\text { yang terjadi } \\
\text { adalah konsep } \\
\text { konduksi* }\end{array}$ & $\begin{array}{c}\text { Sesuai } \\
\text { dengan } \\
\text { konsep } \\
\text { Pemuaian* } \\
\text { hampir tepat } \\
\text { dengan } \\
\text { menggunakan } \\
\text { konsep } \\
\text { pemuaian** }\end{array}$ & $\begin{array}{c}\text { sesuai dengan } \\
\text { konsep } \\
\text { konduksi* } \\
\\
\text { menggunakan } \\
\text { konsep } \\
\text { perpindahan } \\
\text { kalor secara } \\
\text { konduksi* }\end{array}$ & $\begin{array}{c}\text { bahwa yang } \\
\text { dialami adala } \\
\text { perpindahan } \\
\text { kalor secara } \\
\text { konveksi* } \\
\text { mengggunakan } \\
\text { konsep } \\
\text { perpindahan } \\
\text { kalor secara } \\
\text { konveksi* }\end{array}$ & $\begin{array}{c}\text { konsep yang } \\
\text { dipakai adalah } \\
\text { perpindahan } \\
\text { kalor secara } \\
\text { radiasi* } \\
\text { menggunakan } \\
\text { konsep } \\
\text { perpindahan } \\
\text { kalor secara } \\
\text { radiasi* }\end{array}$ & $\begin{array}{c}\text { sesuai dengan } \\
\text { konsep } \\
\text { perpindahan } \\
\text { kalor secara } \\
\text { konveksi* } \\
\text { hampir tepat } \\
\text { dalam } \\
\text { menggunakan } \\
\text { konsep } \\
\text { perpindahan } \\
\text { kalor secara } \\
\text { konveksi* } \\
\end{array}$ \\
\hline 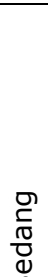 & $R-14$ & $\begin{array}{c}\text { menjawab } \\
\text { hampir tepat } \\
\text { dengan } \\
\text { menggunakan } \\
\text { konsep } \\
\text { pemuaian** }\end{array}$ & $\begin{array}{c}\text { sesuai } \\
\text { dengan } \\
\text { konsep } \\
\text { pemuaian** }\end{array}$ & $\begin{array}{c}\text { tidak sesuai } \\
\text { dengan konsep } \\
\text { fisika yang } \\
\text { dimaksud*** }\end{array}$ & $\begin{array}{c}\text { tidak sesuai } \\
\text { dengan konsep } \\
\text { fisika yang } \\
\text { dimaksud*** }\end{array}$ & $\begin{array}{c}\text { mengatakan } \\
\text { bahwa } \\
\text { lingkungan yang } \\
\text { mempengaruhi } \\
\text { tanpa dielaskan } \\
\text { dengan konsep } \\
\text { fisika yang } \\
\text { dimaksud* }\end{array}$ & $\begin{array}{c}\text { sudah } \\
\text { mendekati } \\
\text { konsep } \\
\text { perpindahan } \\
\text { kalor secara } \\
\text { konveksi* }\end{array}$ \\
\hline जั & $R-33$ & $\begin{array}{c}\text { jawaban } \\
\text { hampir tepat } \\
\text { dan sedikit } \\
\text { sesuai dengan } \\
\text { konsep } \\
\text { pemuaian* }\end{array}$ & $\begin{array}{c}\text { tidak } \\
\text { menjelaskan } \\
\text { detail konsep } \\
\text { pemuaian* }\end{array}$ & $\begin{array}{c}\text { belum sesuai } \\
\text { dengan konsep } \\
\text { yang } \\
\text { dimaksud* }\end{array}$ & $\begin{array}{c}\text { hampir } \\
\text { mendekati } \\
\text { konsep fisika } \\
\text { yang } \\
\text { dimaksud* }\end{array}$ & $\begin{array}{c}\text { hampir tepat } \\
\text { mengenai } \\
\text { sistem ventilasi } \\
\text { didalam } \\
\text { rumah** }\end{array}$ & $\begin{array}{l}\text { hampir tepat } \\
\text { namun tidak } \\
\text { menjelaskan } \\
\text { detail konsep } \\
\text { konveksi** }\end{array}$ \\
\hline$\frac{\check{L}}{\alpha}$ & $R-28$ & $\begin{array}{c}\text { menjawab } \\
\text { dengan konsep } \\
\text { konveksi ketika } \\
\text { kegiatan } \\
\text { wawancara* }\end{array}$ & $\begin{array}{c}\text { sesuai } \\
\text { dengan } \\
\text { konnteks } \\
\text { yang } \\
\text { diberikan } \\
\text { pada konsep } \\
\text { pemuaian* }\end{array}$ & $\begin{array}{c}\text { sesuai dengan } \\
\text { konsep yang } \\
\text { dimaksud** }\end{array}$ & $\begin{array}{c}\text { sesuai dengan } \\
\text { konsep yang } \\
\text { dimaksud** }\end{array}$ & $\begin{array}{l}\text { ventilasi yang } \\
\text { membuat } \\
\text { rumah panas* }\end{array}$ & $\begin{array}{c}\text { tidak } \\
\text { memahami } \\
\text { maksud dari } \\
\text { soal* }\end{array}$ \\
\hline
\end{tabular}

Keterangan:

* : Tidak Konsisten

** : Konsisten Benar

$* * *$ : Konsisten Salah 
Hasil penelitian menunjukkan bahwa konsistensi penalaran yang masih kurang baik dalam hal ketepatan maupun ketidaktepatan pada konsep fisika yaitu pemuaian, perpindahan kalor secara konduksi, dan perpindahan kalor secara konveksi.Konteks atau soal yang berbeda namun dengan konsep yang sama yang diberikan pada responden mempengaruhi konsistensi penalaran siswa dalam pemecahan masalah Pemecahan masalah untuk tahap mengumpulkan fakta, membangun dan menetapkan asumsi, serta menilai dan menguji asumsi yang dilakukan oleh siswa dalam kategori rendah.

Hasil penelitian ini sama dengan penelitian yang dilakukan oleh Prihastuti $^{[8]}$ yang mengungkapkan bahwa sikap konsistensi antara pandangan dan perilaku untuk memecahkan masalah fisika yang dimiliki oleh siswa masih kurang, baik dari segi memahami penyelesaian, merencanakan penyelesaian, menerapkan penyelesaian dan mengecek kembali solusi penyelesaian.

Hasil penelitian ini diperkuat dengan Tongchai $d k k^{[4]}$ yang menyimpulkan bahwa siswa mungkin mampu menjawab pertanyan dengan benar namun masih terdapat kekeliruan pada konsep dasarnya sehingga menyebabkan siswa tidak konsisten dalam menjawab pertanyaan pada tes.

Konsistensi penalaran yang dimiliki siswa dipengaruhi oleh konteks yang berbeda. Hal ini menyebabkan proses penalaran dalam pemecahan masalah yang digunakan pun berbeda-beda.Hasil penelitian ini berbeda dengan penelitian yang dilakukan oleh Marusic dan Slisko ${ }^{[9]}$ yang menyatakan bahwa penalaran peserta didik akan meningkat jika mereka langsung mengamati dan merasakan sendiri suatu permasalahan yang diberikan.

\section{KESIMPULAN}

Berdasarkan analisis data, dapat disimpulkan bahwa penalaran siswa dalam pemecahan masalah fisika untuk konteks yang berbeda menunjukkan bahwa konsistensi penalaran siswa masih kurang. Pemecahan masalah untuk tahap mengumpulkan fakta, membangun dan menetapkan asumsi, serta menilai dan menguji asumsi yang dilakukan oleh siswa dalam kategori rendah.

\section{DAFTAR PUSTAKA}

[1] Fah, L.Y. 2009. Logical Thinking Abilities among Form 4 Students in the Interior Division of Sabah, Malaysia.
p-ISSN 2338-3240, e-ISSN 2580-5924 Journal fo science and Mathematics, education in Southeast Asia, 32(2): 161-187.

[2] Polya. (1957). How To Solve It? A New Aspect of Mathematical Methot (2nd Edition). New Jersey: Princeton University Press.

[3] Subaer. Profil Penalaran berdasarkan Gaya Berpikir dalam Memecahkan Masalah Fisika Peserta Didik. Jurnal Pendidikan IPA Indonesia. 2013

[4] Tongchai, Apisit. et al. (2011). Consistency of students' conceptions of wave propagation: Findings from a conceptual survey in mechanical waves. [Online]. Tersedia: http://journals.aps.org/prstper/abstract/10.1103/Phys Rev STPER7.020101. [1 Juli 2015].

[5] Gibson, V., Jardine, W.L. and Bateman, E. (2015). "An Investigation Into The Impact Of Question Structure On The Performance Of First Year Physics Undergraduate Student At The University Of Cambridge".European Journal of Physics.36 045014 (17pp).

[6] Bektasli, Behzat. (2011). consistency of students ideas about the concept of rate across different contexts. Journal of Turkish Science Education.

[7] Nieminen Pasi, Antti Savinainen, \&Jouni Viiri. (2010). Force Concept Inventory-based multiple-choice test for investigating students' representational consistency. Department of Teacher Education, University of Jyväskylä, Jyväskylä FIN-40014, Finland.

[8] Prihastuti, A. (2013). Konsistensi antara Pandangan dan Prilaku Siswa Dalam Memecahkan Masalah Fisika.Skripsi pada Program Studi Pendidikan Fisika FKIP. Universitas Tadulako Palu: tidak diterbitkan.

[9] Marusic, Mirko \& Slisko, Josip. 2012. Influence of Three Different Methods of teaching Physics on the Gain in students' Development of Reasoning. Internasional journal of science Education, 34 (2): 301-326. 